\section{THE EFFECT OF ETHANOL ON FUEL TANK CORROSION RATE}

\author{
Muji Setiyoa*, Saifudina, Abdul Wahid Jamina, Rifqi Nugrohoa, Djoko \\ Wahyu Karmiadjib
}
aDepartment of Automotive Engineering, Universitas Muhammadiyah Magelang, Magelang, Indonesia bAgency for the Assessment and Application of Technology, PUSPITEK Serpong, Indonesia .

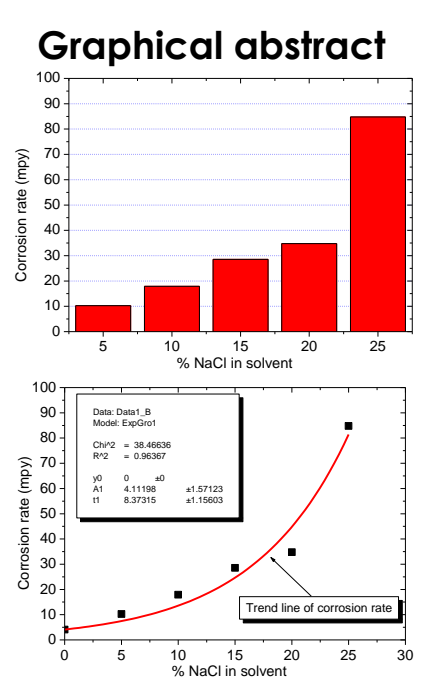

\begin{abstract}
In recent decades, the use of ethanol as an alternative fuel for S.I engines has become a popular issue. This is not only due to availability and oil prices, but also to address concerns about the increase in greenhouse gas effects. However, ethanol is corrosive in a fuel tank made of metal, because it contains soluble chloride ions. Therefore, this paper presents the results of an investigation of the fuel tank corrosion rate made of metal FE_U_100 due to the use of pure ethanol. The test was performed by PGS-120T potentiostat with the addition of $\mathrm{NaCl}$ in ethanol in concentrations of $5,10,15,20$, and $25 \%$ while the estimated corrosion rate on pure ethanol was done by regression. The estimation of the fuel tank corrosion rate through the exponential regression for the use of pure ethanol is 4,116 mpy. Then, from the assessment metrics, the fuel tank made of Fe_U_100 has corrosion resistance in the excellent category. This means no fuel tank modification or replacement is required for pure ethanol applications in S.I. engine.
\end{abstract}

Keywords: Ethanol, S.I. engine, fuel tank, potentiostat, corrosion rate

(C) 2018 Penerbit UTM Press. All rights reserved

\subsection{INTRODUCTION}

In the last few decades, the availability of fossil fuels has been a concern of many stakeholders [1-2]. Crude oil products from current production fields may have passed the peak of production. The peak oil issues will cause oil to become scarce, the cost and demand of oil products will increase, while the supply is limited [35]. In addition to oil production, another crisis issue is related to global climate change caused by the burning of fossil fuels. If it is not controlled, the costs and challenges of reducing greenhouse gas (GHG) emissions will increase along with time. To overcome the climate changes and greenhouse gas emissions, one effective way is to act immediately in to replacing fossil fuels with renewable fuels, such as ethanol/bioethanol for Spark Ignition (S.I.) engines and Compression Ignition
(C.I.) engines [6-7]. The application of ethanol in the S.I. engine is relatively easier and can be accepted by all types of Ligh Duty Vehicles (LDVs). However, the applications on C.I. engines must be accompanied with some engine modifications and the use of cetane enhancers[8]. Nevertheless, some researchers report that the addition of $10 \%$ ethanol in diesel engines is capable of producing better engine performance and emissions [9-11].

In the early years of the history of car labout a century ago), ethanol did not promise to be used because its production was insufficient and its price was uneconomical. However, with the advanced production technology and can be made widely from biomass, one day the price can compete with highquality fossil fuels [12]. As explained earlier, the use of ethanol begins from an awareness of the depletion of 
petroleum reserves. On the other hand, the use of ethanol is to improve the air quality, especially in urban areas [13]. The comparison of ethanol to gasoline and methanol properties is given in Table 1.

In the last decade, ethanol production for road vehicle sector is increasing [14-15], which means it brings a positive impact on local and regional economies [9]. However, large-scale production will be constrained by the availability of land for food production. Ethanol is commonly used as a blend in gasoline with the concentrations of $5 \%$ to $85 \%$ (E5, E85) [8], although it can be identified as a full dedicated fuel (100\%). The use of Ethanol has become an energy policy in several countries such as Brazil, the United States, Argentina, and some countries in the Americas and Europe [3]. Now, many countries are pushing to sell gasoline-alcohol mixtures in fuel stations because fuel oil causes high exhaust emissions, including gases like $\mathrm{CO}$ (carbon monoxide), $\mathrm{CO}_{2}$ (carbon dioxide), $\mathrm{NOx}$ (nitrogen oxides), and particulates.

Table 1 Comparison of ethanol to gasoline and methanol [16]

\begin{tabular}{|c|c|c|c|}
\hline Fuel & Gasoline & Ethanol & Methanol \\
\hline Typical formula & $\mathrm{C}_{6.97} \mathrm{H}_{14.02}$ & $\mathrm{C}_{2} \mathrm{H}_{5} \mathrm{OH}$ & $\mathrm{CH}_{3} \mathrm{OH}$ \\
\hline $\begin{array}{l}\text { Density ( } \mathrm{kg} \mathrm{m}^{-3} \text { at } \\
\left.15^{\circ} \mathrm{C}\right)\end{array}$ & 750.8 & 809.9 & 796 \\
\hline $\begin{array}{l}\text { Research octane } \\
\text { number }\end{array}$ & 95 & 108.6 & 108.7 \\
\hline $\begin{array}{l}\text { Motor octane } \\
\text { number }\end{array}$ & 85 & 89.7 & 88.6 \\
\hline $\begin{array}{l}\text { Kinematic viscosity } \\
\left(\mathrm{mm}^{2} \mathrm{~s}^{-1} \text { at } 40^{\circ} \mathrm{C}\right)\end{array}$ & 0.494 & 1.221 & 0.596 \\
\hline Heating value $\left(\mathrm{kJ} \mathrm{kg}^{-1}\right)$ & 42.6 & 26.7 & 19.85 \\
\hline $\begin{array}{l}\left.\text { Heating value (MJ } \mathrm{m}^{-3}\right) \\
\text { Distillation\% }\end{array}$ & 31.985 & 21.625 & 15.8 \\
\hline Initial boiling point & 45 & 78 & 64 \\
\hline 50 & 96 & 78 & 64 \\
\hline 90 & 168 & 79 & 65 \\
\hline End boiling point & 207 & 79 & 66 \\
\hline
\end{tabular}

Initially, vehicles that run by gasoline-ethanol blend produce less power than the use of pure gasoline. In line with research and development activities to improve compression ratio, injection time, and ignition time, the problem in power loss can be reduced[16-17]. Ozsezen and Canakci [18] tested an alcohol-gasoline mixture on S.I. The result shown that the engine power was slightly increased compared to pure gasoline. Indeed, the fuel consumption of the alcohol-gasoline mixture is slightly higher than that of pure gasoline to achieve the same power. However, the gasoline-alcohol mixture at all vehicle speeds gives slightly higher combustion efficiency compared to pure gasoline.

Moreover, ethanol is not as strong as gasoline, which means there are problems during winter or in extremely cold weather. However, there are solutions to for this problem, including adding additives or adjusting the percentage of concentration at cold start condition [11]. As an alternative fuel, ethanol has the advantage of being renewable and has an octane rating higher than gasoline. It is possible to apply ethanol to in a high compression ratio (up to 19.5) to improve thermal efficiency and exhaust emissions. In fact, for highconcentration ethanol applications, the modifications required not only in compression ratio, but also in some engine components in order for the vehicle to run smoothly and prevent them from damage. In a study that used a complex engine control system and an optimized exhaust recirculation system, a car running on the E50 is capable of producing fuel efficiency equivalent to a gasoline car [19]. Table 2 presents the engine and vehicle components that must be adjusted in the application of ethanol blend from low to high concentration.

Table 2 Resetting on a S.I. engine to use ethanol fuel [20]

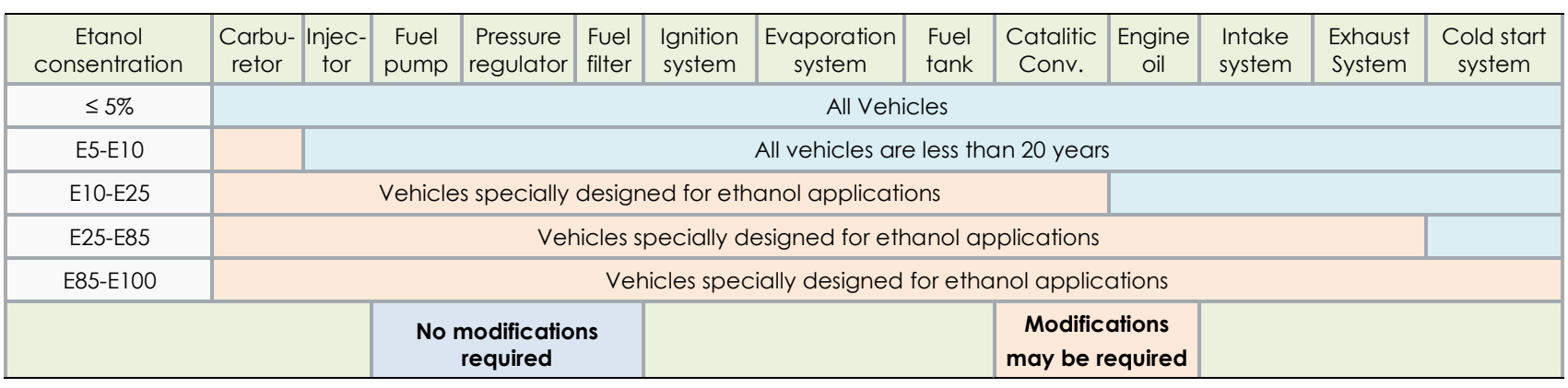

However, Ethanol contains soluble and insoluble elements [21]. The soluble element is chloride ions which have corrosive properties. Ions will attack the passivation of the oxide film on the metal so it will corrode and increase the fuel conductivity. Soluble elements, such as aluminum hydroxide, will clog the fuel system. Ethanol is hygroscopic which absorbs moisture directly from the atmosphere. The water content in ethanol will decrease the combustion energy and cause knocking on the engine. To avoid such risks, the ethanol must be sealed during storage. However, this procedure becomes difficult because the fuel tank should be provided ventilation valve to prevent vacuum. 
Corrosion will damage metals, including fuel tanks, fuel system components made of plastic and rubber, injectors, and emerging deposits. In 2001, several models of vehicles that used alcohol fuels in Japan reportedly experienced fuel leaks and fires due to corrosion in fuel system components made of aluminum. Then, an investigation is done by a team. To prove the case, the immersion test was performed on metals and other materials used for the fuel system part to determine the corrosion resistance of ethanol contained in the fuel. The results of this study indicate that a high concentration of ethanol cause corrosion in the fuel system components made of aluminum [22]. Other studies related to the effects of ethanol on the corrosion of fuel tanks and fuel pipelines also have been done by Singh, Rawat, Kane, and Matějovský [23-26].

In 2015, a team from the Gasoline and Diesel Engines Laboratory of Universitas Muhamadiyah Magelang has tested the fuel tank corrosion rate due to the E10 to E30 applications. The method used is by conventional immersion method to the sample of the fuel tank for two months. Each week the sample is removed, cleaned, and checked for weight loss. However, this method has not provided valid corrosion rate data due to the limitation on equipment [27]. Therefore, as a follow-up of the previous study, this research is to test the corrosion resistance of fuel tank using the potentiostat method.

\subsection{METHODOLOGY}

\subsection{Specimen Preparation}

In this study, a tank was cuted into test specimens. Some of the specimens were subjected to a material composition test using IK 5.4-1-1 method in the Metal Testing Laboratory at the Ceper Manufacturing Polytechnic, Klaten, Indonesia. The result of material composition shows that the fuel tank tested is a steel with Grade Fe_U_100. Then, the other pieces are formed in a circular dish with an area of $170 \mathrm{~mm}^{2}$ as shown in Figure 1. The specimen's surface is then smoothed and polished with 1000 mesh sandpaper.
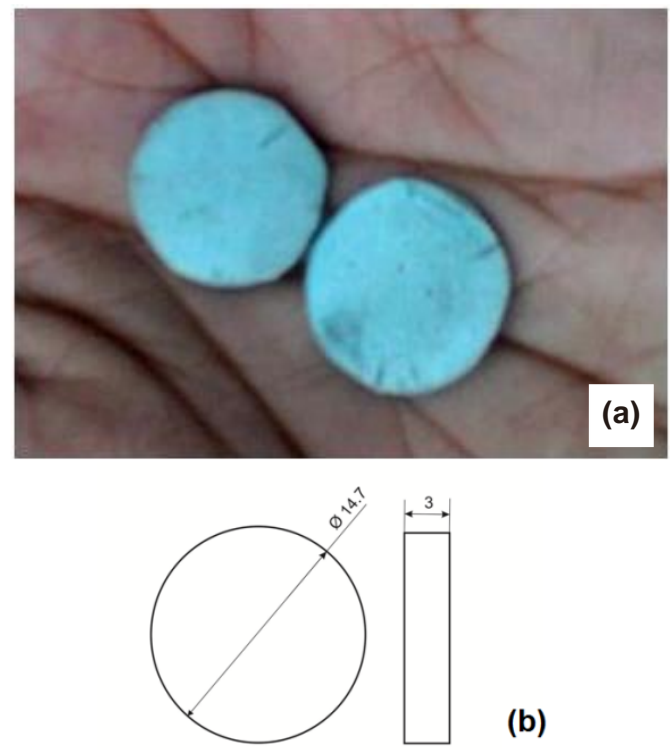

(b)

Figure 1 The specimens of fuel tank: (a) Photographic view of the specimens and (b) the dimension of specimen (in $\mathrm{mm}$ )

\subsection{Corrosion Solvent}

After the specimens are completed, the next step is to preparing the solvent to test the corrosion resistance. Since ethanol can not conduct an electric current, $\mathrm{NaCl}$ is added to the ethanol. Variations in the ethanol- $\mathrm{NaCl}$ used are shown in Table 3.

Table 3 Solvent for corrosion testing

\begin{tabular}{|c|l|c|}
\hline Sample & \multicolumn{1}{|c|}{ Solvent } & $\begin{array}{c}\% \mathrm{NaCl} \text { in } \\
\text { solvent }\end{array}$ \\
\hline \multirow{4}{*}{$090 / \mathrm{P} / \mathrm{STA} / 17$} & Ethanol $190 \mathrm{ml}+10 \mathrm{ml} \mathrm{NaCl}$ & 5 \\
\cline { 2 - 3 } & Ethanol $180 \mathrm{ml}+20 \mathrm{ml} \mathrm{NaCl}$ & 10 \\
\cline { 2 - 3 } & Ethanol $170 \mathrm{ml}+30 \mathrm{ml} \mathrm{NaCl}$ & 15 \\
\cline { 2 - 3 } & Ethanol $160 \mathrm{ml}+40 \mathrm{ml} \mathrm{NaCl}$ & 20 \\
\cline { 2 - 3 } & Ethanol $150 \mathrm{ml}+50 \mathrm{ml} \mathrm{NaCl}$ & 25 \\
\hline
\end{tabular}

\subsection{Test Equipment}

The corrosion test apparatus used is the PGS-201T potentiostat as shown in Figure 2. The testwas conducted at the National Nuclear Power Agency, Yogyakarta, Indonesia. The specimen is attached to the working electrode with a shiny surface facing out to be immersed in the solution Then, it was attached to the electrochemical cell. The columnel and platinum electrodes are mounted on the electrochemical cell. A $200 \mathrm{ml}$ corrosion solution is introduced into the electrochemical cell until all electrodes are dyed. Then, all electrodes are connected to the IMT-1 interface. IMT-1 program is an 
interface code of the computer as a device of the PGS-201T potentiostat). Potentiostat and IMT-1 interface is turned on until the process of data transfer on the microcomputer.

Measurements were made by giving a working electrode potential of $-2000 \mathrm{mV}$ to $+2000 \mathrm{mV}$ with a scan rate of $20 \mathrm{mV} / \mathrm{s}$ through the operation of a microcomputer that provides the output of a potential curve versus the log of current intensity. All solutions, before and after treatment measured its conductivity and $\mathrm{PH}$. All measuring activities are carried out at room temperature of $25^{\circ} \mathrm{C}$.

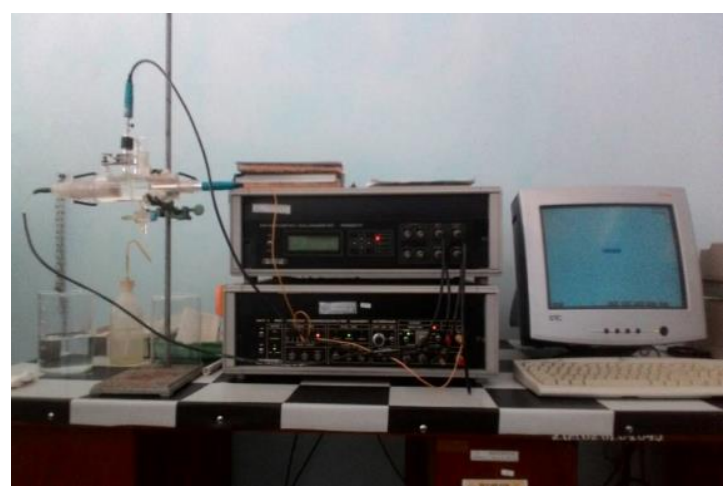

Figure 2 Potensiostat equipment

\subsection{Corrosion Rate Calculation}

By using the electrochemical method, the corrosion rate is measured based on the potential difference of the object to obtain the corrosion rateoccured. This electrochemical method uses the formula based on Faraday's Law presented in equation (1) [28].

$$
C R=K \frac{a I}{n D}
$$

Where, $C R$ is corrosion rate (mpy), $K$ is constant factor (mpy=0.129), $a$ is atomic weight of metal, $I$ is current density $\left(\mu \mathrm{A} / \mathrm{cm}^{2}\right), n$ is number of electron loss, and $D$ is metal density $\left(\mathrm{g} / \mathrm{cm}^{3}\right)$.

\subsection{RESULTS AND DISCUSSION}

\subsection{Test Result}

In this study, the corrosion testing was performed alternately for 5 samples with one test instrument. The results of corrosion testing are presented in Figure 3, which indicates that higher levels of $\mathrm{NaCl}$ in ethanol increased the current density. After corrosion test data was known, then, the calculation of corrosion rate was done by considering material density and atomic valence obtained from composition test. The corrosion rate is presented in Table 4 and Figure 4, respectively. It is seen that the increase of $\mathrm{NaCl}$ content in the solution followed by an increase in corrosion rate. 

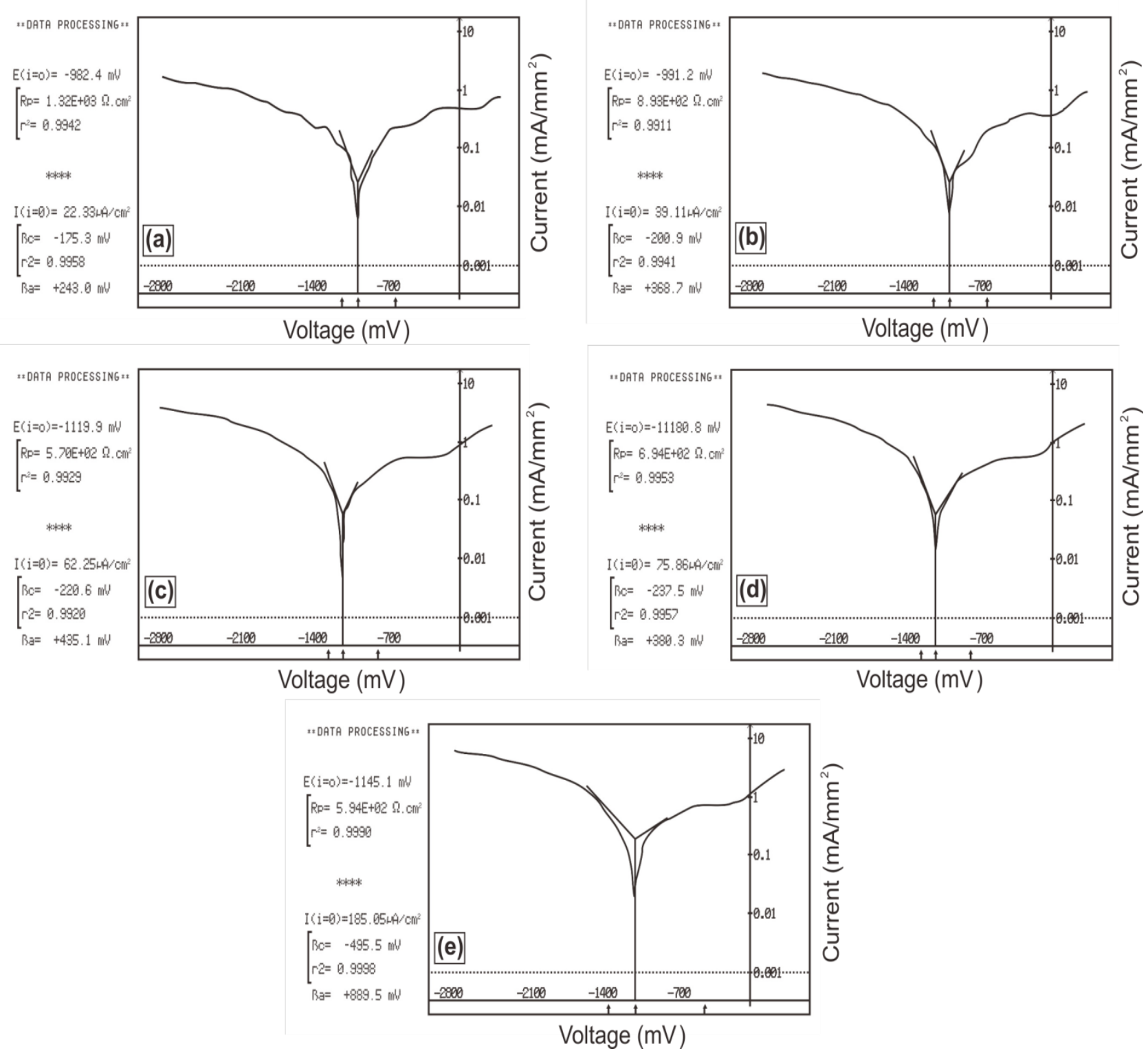

Figure 3 Corrosion test results for all solvents used: (a) $5 \% \mathrm{NaCl}\left(\mathrm{l}=22.33 \mu \mathrm{A} / \mathrm{cm}^{2}\right)$; (b) $10 \% \mathrm{NaCl}\left(\mathrm{I}=39.11 \mu \mathrm{A} / \mathrm{cm}^{2}\right) ;(\mathrm{c}) 15 \% \mathrm{NaCl}$ $\left(I=62.25 \mu \mathrm{A} / \mathrm{cm}^{2}\right)$; (d) $20 \% \mathrm{NaCl}\left(\mathrm{l}=75.86 \mu \mathrm{A} / \mathrm{cm}^{2}\right)$; and (e) $20 \% \mathrm{NaCl}\left(\mathrm{l}=75.86 \mu \mathrm{A} / \mathrm{cm}^{2}\right)$

Table 4 Corrosion rate calculation

\begin{tabular}{|c|c|c|c|c|c|c|c|}
\hline \multirow[t]{2}{*}{ Solvent } & \multirow{2}{*}{$\begin{array}{l}\% \mathrm{NaCl} \\
\text { in } \\
\text { solvent }\end{array}$} & $\begin{array}{l}\text { Atomic } \\
\text { weight }\end{array}$ & $\begin{array}{l}\text { Current } \\
\text { density }\end{array}$ & $\begin{array}{c}\text { Atomic } \\
\text { valence } \\
\text { (Fe_U_100) }\end{array}$ & $\begin{array}{c}\text { Metal } \\
\text { density }\end{array}$ & \multirow[t]{2}{*}{$K$} & \multirow[t]{2}{*}{$\begin{array}{c}\text { Corrosion rate, } \\
\text { CR (mpy) }\end{array}$} \\
\hline & & $a=M$ & I & $n$ & $D$ & & \\
\hline Ethanol $190 \mathrm{ml}+10 \mathrm{ml} \mathrm{NaCl}$ & 5 & 55,845 & 22,33 & 2 & 7,86 & 0.129 & 10,23316995 \\
\hline Ethanol $180 \mathrm{ml}+20 \mathrm{ml} \mathrm{NaCl}$ & 10 & 55,845 & 39,11 & 2 & 7,86 & 0.129 & 17,92294119 \\
\hline Ethanol $170 \mathrm{ml}+30 \mathrm{ml} \mathrm{NaCl}$ & 15 & 55,845 & 62,25 & 2 & 7,86 & 0.129 & 28,52730988 \\
\hline Ethanol $160 \mathrm{ml}+40 \mathrm{ml} \mathrm{NaCl}$ & 20 & 55,845 & 75,86 & 2 & 7,86 & 0.129 & 34,76436510 \\
\hline Ethanol $150 \mathrm{ml}+50 \mathrm{ml} \mathrm{NaCl}$ & 25 & 55,845 & 185,95 & 2 & 7,86 & 0.129 & 84,80287056 \\
\hline
\end{tabular}




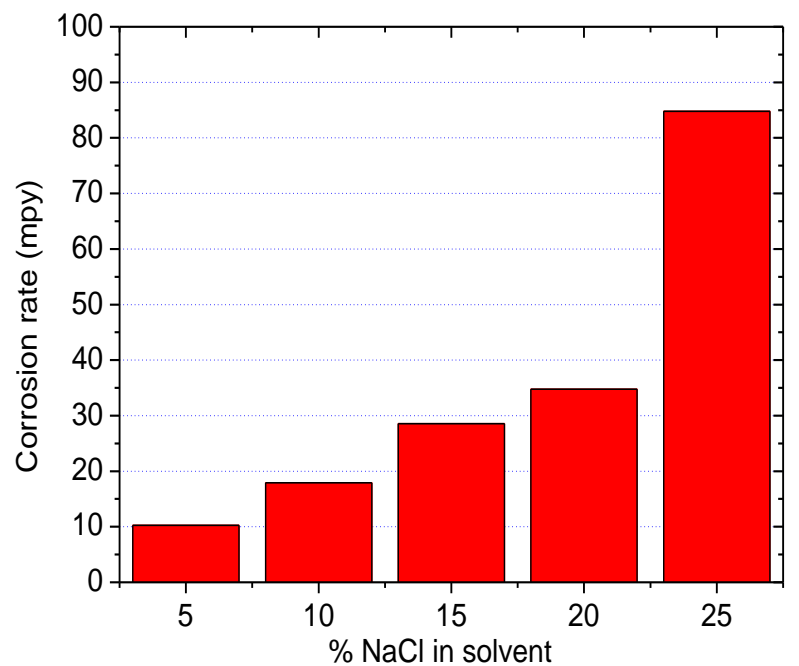

Figure 4 Percentage of $\mathrm{NaCl}$ in solvent to the trend of corossion rate

\subsection{Corrosion Rate Estimation for Pure Ethanol}

To determine the corrosion rate in pure ethanol by using an exponential regression with response $(y)$ and predictor $(x)$ obtained from Table 4 . Where, the value of $x$ is the percentage of $\mathrm{NaCl}$ in the solvent and $y$ is the corrosion rate in mpy. The exponential regression obtained from software Origin 6.0 is $y=y_{0}+A_{1} e^{\left(\frac{x}{t 1}\right)}$, where the value $A_{1}$ is 4.166 and $t_{1}$ is 8.37. Thus, the corrosion rate for pure ethanol can be estimated as follows.

$$
\begin{aligned}
& y=y_{0}+A_{1} e^{\left(\frac{x}{t 1}\right)} \\
& y=0+(4.166) e^{\left(\frac{0}{8.37}\right)} \\
& y=4.166[m p y]
\end{aligned}
$$

In graphical form, the exponential curve of the corrosion rate is presented in Figure 5.

In another recent study conducted by Thangavelu et al. [29], ethanol effects on corrosion rates on materials made of mild steel $(0.2 \%$ C, $0.4 \% \mathrm{Mn}$ and $99.4 \% \mathrm{Fe})$, copper (99.99\%) and aluminum $199 \%$ commercially pure) were studied. A submersion method was performed to test the material's resistance to exposure to ethanol mixed in low-grade biodiesel. The results of this study show that the corrosion rates for E5 and E10 at room temperature are 0.1572 and $0.1817 \mathrm{mpy}$, respectively. If this result is extrapolated linearly to E100, the corrosion rate at E100 is about 0.6627 mpy. This study also concluded that mild steel(MS) corrosion resistance is better than Aluminium (Al) but worse than copper (CU).

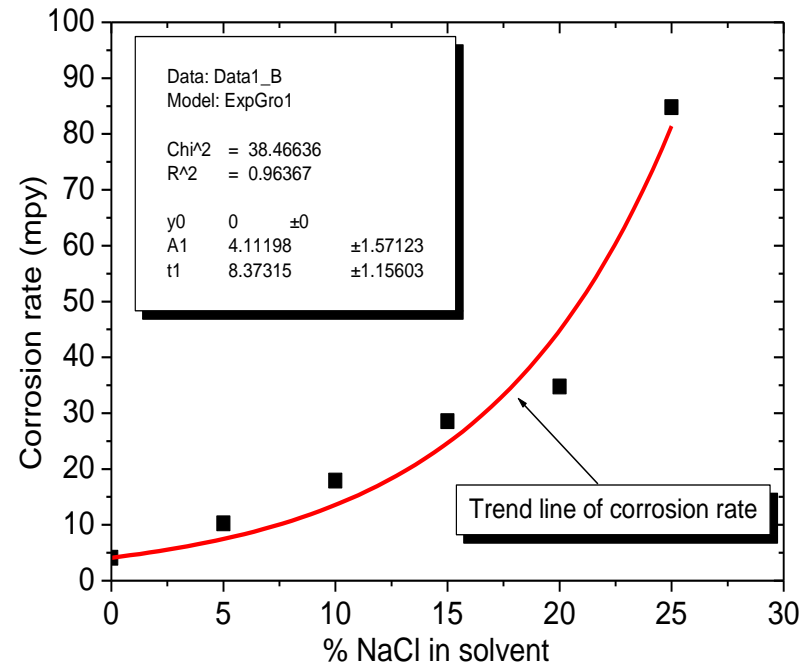

Figure 5 Exponential regression of corossion rate

In the present study, a corrosion rate of 4,166 mpy showed a lower value than the results of investigations conducted by Rawat [22] who reported a corrosion rate on carbon steel exposed $100 \%$ ethanol (E100) was between 10 and 12 mpy. Meanwhile, with the addition of an inhibitor, the corrosion rate can be reduced to 4-5 mpy.

\subsection{Corrosion Resistance Analysis}

After the corrosion rate is known, then, an assessment of the corrosion resistance of the tank is performed. The assessment is divided into 6 categories: outstanding, excellent, good, fair, poor, and unacceptable, respectively. The parameters used to assess are presented in Table 5.

Table 5 Corrosion resistance assessment matrix [28]

\begin{tabular}{|c|c|c|c|c|c|}
\hline \multirow{2}{*}{$\begin{array}{c}\text { Relative } \\
\text { Corrosion } \\
\text { Resistance }\end{array}$} & \multicolumn{5}{|c|}{ Aproximate Metric Equivalent } \\
\cline { 2 - 6 } & $\mathbf{m p y}$ & $\mathbf{m m} /$ year & $\boldsymbol{\mu m} /$ year & $\mathbf{n m} /$ year & $\mathbf{p m} / \mathbf{s c}$ \\
\hline Outsatnding & $<1$ & $<0.02$ & $<25$ & $<2$ & $<1$ \\
\hline Excellent & $1-5$ & $0.02-0.1$ & $25-100$ & $2-10$ & $1-5$ \\
\hline Good & $5-20$ & $0.1-0.5$ & $100-500$ & $10-50$ & $5-20$ \\
\hline Fair & $20-50$ & $0.5-1$ & $500-1000$ & $50-100$ & $20-50$ \\
\hline Poor & $50-200$ & $1-5$ & $1000-5000$ & $100-500$ & $50-200$ \\
\hline Unacceptable & $200+$ & $5+$ & $5000+$ & $500+$ & $200+$ \\
\hline
\end{tabular}

The estimation of the fuel tank corrosion rate through the exponential regression for the use of pure ethanol is $4.116 \mathrm{mpy}$. Then, from the assessment metrics, the fuel tank made of Fe_U_100 has corrosion resistance in the excellent category. This means no fuel tank modification or replacement is required for the pure ethanol applications in S.I. engine. 


\subsection{CONCLUSION}

The results of this study indicate that the fuel tank made of Fe_U_100 has excellent ability against corrosion attack due to the use of pure ethanol. The estimated corrosion rate obtained by exponential regression for the use of pure ethanol is $4,116 \mathrm{mpy}$. In the relative corrosion resistance metrics, the corrosion rate of 4,116 is categorized as "excellent". This research will continue with the inspection of other fuel components such as pipe line, injector, pressure regulator diaphragm, and fuel pump.

\section{Acknowledgement}

This research is fully supported by Ministry for Research, Technology, and Higher Education, Republic of Indonesia. This work was managed by Research Division of Universitas Muhammadiyah Magelang. The researchers are grateful to both institutions.

\section{References}

[1] Akpan, U. G., Alhakim, A. A. \& ljah, U. J. J. 2008. Production of Ethanol Fuel from Organic and Food Wastes. Leonardo Electronic Journal of Practices and Technologies. 7(13): 001-011.

[2] Adam, I. K., Galadima, A. \& Muhammad, A. I. 2011. Biofuels in the Quest for Sustainable Energy Development. Journal of Sustainable Development. 4(3): 10-19. Available at: http://www.ccsenet.org/journal/index.php/jsd/article/vie $w / 10884$.

[3] Carlsson, H. \& Fenton, P. 2010. BioEthanol for Sustainable Transport - Results and Recommendations from the European Best Project, Stockholm.

[4] IEA. 2015. World Energy Outlook 2015, Paris.

[5] Sorrell, S. et al. 2009. Global Oil Depletion: An Assessment of the Evidence for a Near-term Peak in Global Oil Production, Available http://linkinghub.elsevier.com/retrieve/pii/S0301421510003 204.

[6] EAA. 2009. Annual Report 2008 and Environmental Statement 2009, Copenhagen. Available at: http://www.pedz.uni-mannheim.de/daten/edzbn/gdf/09/Annual-report-2008.pdf.

[7] Demirbas, A. 2011. Competitive Liquid Biofuels from Biomass. Applied Energy. 88(1): 17-28. Available at: http://dx.doi.org/10.1016/j.apenergy.2010.07.016.

[8] ETSAP, I. E. A. 2010. Ethanol Internal Combustion Engines. Technology Brief T06. (June): 1-6.

[9] Labeckas, G., Slavinskas, S. \& Maz, M. 2014. The Effect of Ethanol - Diesel - Biodiesel Blends on Combustion, Performance And Emissions of a Direct Injection Diesel Engine. Energy Conversion and Management. 79(2014): 698-720. doi: 10.1016/j.enconman.2013.12.064.

[10] Shahir, S. A. et al. 2015. Performance and Emission Assessment of Diesel - Biodiesel - Ethanol / Bioethanol Blend as a Fuel in Diesel Engines: A Review. Renewable and Sustainable Energy Reviews. 48(2015): 62-78. Available at: http://dx.doi.org/10.1016/j.rser.2015.03.049.

[11] Yilmaz, N. et al. 2014. Investigation of $\mathrm{Cl}$ Engine Emissions in Biodiesel - Ethanol - Diesel Blends as a Function of Ethanol
Concentration. Fuel. 115(2014): 790-793. doi: 10.1016/j.fuel.2013.08.012.

[12] Cardona, C. A. 2007. Fuel Ethanol Production: Process Design Trends and Integration Opportunities. Bioresource Technology. 98(12): 2415-2457. Available at: http://www.sciencedirect.com/science/article/pii/S09608 52407000156.

[13] U.S Department of Energy. 2005. Low-Level Ethanol Fuel Blends. Clean Cities, (April). Available at: www.eere.energy.gov/cleancities.

[14] EPURE. 2015. European Renewable Ethanol: State of the Industry Report. Energy, (August).Available at: http://epure.org/media/1215/epure_state_industry2015_w eb.pdf.

[15] Renewable Fuels Association. 2016. 2016 Ethanol Industry Outlook, Washington, DC: RFA. Available at: www.ethanolRFA.org.

[16] Gaurav, T. \& Nitin, S. 2014. Experimental Investigation of Ethanol Blends with Gasoline on SI Engine. Int. Journal of Engineering Research and Applications. 4(10): 108-114.

[17] Ahmed, M. A., Ismail, Y., \& Mohamed, M. 2017. The Influence of Ethanol-Gasoline Blends on Performance Characteristics of Engine Generator Set. American Journal of Engineering Research. 6(9): 71-77.

[18] Ozsezen, A. N. \& Canakci, M. 2011. Performance and Combustion Characteristics of Alcohol E Gasoline Blends at Wide-open Throttle. Energy. 36(5): 2747-2752. Available at: http://dx.doi.org/10.1016/j.energy.2011.02.014.

[19] Bakenhus, M. 2016. Economical, High-Efficiency Engine Technologies for Alcohol Fuels. American Energy Independence. Available at https://archive.epa.gov/otaq/technology/web/pdf/epafev-isaf-no55.pdf.

[20] The Royal Society. 2008. Sustainable biofuels: prospects and challenges, Available at http://royalsociety.org/uploadedFiles/Royal_Society_Cont ent/policy/publications/2008/7980.pdf.

[21] Brinkman, N. D. et al. 1994. The Development of Improved Fuel Specifications for Methanol (M85) and Ethanol (Ed85) SAE Technical Paper. 1994-3-1.doi:10.4271/940764.

[22] Kameoka, A. et al. 2005. Effect of Alcohol Fuels on Fuel-Line Materials of Gasoline Vehicles. Powertrain \& Fluid Systems Conference \& Exhibition Technical Papers. (2005-01-3708).

[23] Singh, R. 2009. Ethanol Corrosion in Pipelines. Material Performance. (May): 9-11.

[24] Rawat, J., Rao, P. V. C. \& Choudary, N. V. 2008. Effect of Ethanol-Gasoline Blends on Corrosion Rate in the Presence of Different Materials of Construction used for Transportation. SAE Technical Paper. 2008-281 (November)

[25] Kane, R. D. 2009. Ethanol and Stress Corrosion Cracking in Petroleum Storage Tanks. NACE Corrosion Conference and Expo. 1-16.

[26] Lukáš M., Jan M., Milan P., Petr B., Martin S. \& Aneta K, 2017. Study of Corrosion of Metallic Materials in Ethanol-Gasoline Blends: Application of Electrochemical Methods. Energy Fuels, 31 (10), pp 10880-10889.

[27] Fahmi, L. \& Setiyo, M. 2015. Effect of Ethanol Blend on Corrosion Rate of Fuel Tank (original: Pengaruh Campuran Ethanol Pada Laju Korosi Tangki Bahan Bakar). In Semnastek. Jakarta: Fakultas Teknik Universitas Muhammadiyah Jakarta. 1-6.

[28] Fontana, M. 1987. Corrosion Engineering, New York: McGraw-Hill. Available at: http://dl.iranidata.com/book/daneshgahi/MarsFontanaCorrosionEngineering(www.iranidata.com).pdf.

[29] Kannan, S., Saleh, A. \& Nasir, F. 2016. Impact of Metals on Corrosive Behavior of Biodiesel e Diesel e Ethanol (BDE) Alternative Fuel. Renewable Energy. 94: 1-9. http://dx.doi.org/10.1016/j.renene.2016.03.015. 